\title{
WHEN FINNISH AND KARELIAN PERSON SYSTEMS COME TOGETHER: COMPARING OPEN PERSON CONSTRUCTIONS IN BORDER KARELIAN DIALECTS
}

\author{
Milla Uusitupa \\ University of Eastern Finland, FI \\ milla.uusitupa@uef.fi
}

\begin{abstract}
This article is a contribution to the recent discussion on open reference and especially on open second-person singular usage in Finnish and other European languages. The article focuses on four referentially open person constructions - namely the zero construction, the necessive construction, the second-person singular construction, and the imperative construction - and their interplay and variation in spoken discourse in Border Karelian dialects. The aim of this article is three-fold. First and foremost, it argues that the aforementioned open person constructions are fundamentally four separate types. Second, it aims to expand the on-going discussion on open reference in Finnish by introducing the person system of its closely related but highly endangered cognate language, Karelian. Third, it raises the following question: In a wider Finnic context, is the zero construction, above all, a Finnish way of leaving the reference open and unspecified?
\end{abstract}

Keywords: open reference, impersonal reference, Border Karelian dialects, Karelian, Finnish

DOI: https://doi.org/10.12697/jeful.2021.12.1.11

\section{Introduction}

In recent decades, the grammatical expression of person category has attracted growing interest in both Finnish linguistics and in crosslinguistic studies. Of special interest has been referentially impersonal person constructions, which construe an experience of a potential human referent, or a group of potential human referents, whose identity is left unspecified (e.g. Siewierska 2004: 210). In this article, I will follow the tradition of Finnish linguistics and call these constructions referentially open (e.g. Laitinen 2006, Helasvuo 2008, Suomalainen 2018). By using the term 'open reference', I wish to emphasise that the reference is 
only interpreted in the context, and although open person constructions describe a situation in a generalised way, both speaker and listener can, at least in principle, recognise it and perhaps even relate to it (also Varjo \& Suomalainen 2018: 337).

The present study focuses on four grammatical strategies to construe an open reference in border dialects of Finnish and Karelian. The constructions discussed are the following:

- zero construction (hereinafter 3SG)

- necessive construction (hereinafter NEC)

- open second-person singular construction (hereinafter 2SG)

- open imperative construction (hereinafter IMP)

All four constructions are widely used in Border Karelian dialects, which constitute a transition zone between Eastern Finnish dialects and their closest linguistic relative, the Karelian language. Although Eastern Finnish and Karelian are closely related, there are significant differences in their ways of person marking, in general, and expressing an open reference. In Finnish, the most common means to construe an open reference is the $3 \mathrm{SG}$ construction, while the $2 \mathrm{SG}$ is used mainly in Southeastern dialects (Sirelius 1894, Forsberg \& Uusitupa 2015). When it comes to Karelian, the situation is quite the opposite: the 2SG is the primary means for open reference, and 3rd person singular is almost exclusively used with modal predicates, as will be demonstrated in the following. The NEC construction stands out from the rest in that it is impersonal both semantically and morphologically, i.e. its predicate verb appears always in 3rd person singular. Similarly, the IMP construction has certain inflectional restrictions. With open IMP construction I refer to referentially open second-person singular imperative clauses that are reasonable to separate from other $2 \mathrm{SG}$ clauses because of their syntactic and semantic characteristics (in more detail below). The article is based on my doctoral dissertation in which I analysed the open person constructions in Border Karelian dialects from functional and interactional perspectives (Uusitupa 2017). In the present article, in contrast, the focus is on the frequencies and areal variation of different construction types, and the various discourse functions will be left out.

The article is structured as follows: Section 2.1 outlines the theoretical starting point by discussing the concept of open reference and its relation to the more widely used concept of impersonality, Section 2.2 
introduces the history of Border Karelian dialects, and Section 2.3 provides general information about person marking in both languages. The person constructions under investigation are introduced in Section 3, and the data and methods are described in Section 4. Sections 5 to 7 comprise the analysis, proceeding from areal distribution (Section 5) to analysing the predicates of each construction type (Section 6) and comparing findings with the Tver Karelian comparison corpus (Section 7). Section 8 provides a summary and conclusions. Section 8 also posits additional questions about open reference in the Finnic context.

\section{Background}

\subsection{Impersonal and open reference}

In the literature, impersonal constructions do not form a uniform or clearly defined class. Instead, in different research traditions and in different fields of linguistics, the concept has divergent definitions, some of them based on semantics and some of them on structure (Malchukov \& Siewierska 2011). According to Helasvuo and Vilkuna (2008: 217), a construction can be considered as impersonal if: a) it lacks a grammatical person opposition, b) it lacks an agent or other primary argument, c) its primary argument is coded in a non-subject-like (oblique) manner, or d) the identity of the primary argument is left unspecified.

In this article, the most relevant definition is the last-mentioned, based on the reference. Referentially impersonal constructions, denoted herein as R-impersonals, are structurally regular person constructions but have a notional subject that lacks the referential properties of a proto-typical subject (Malchukov \& Ogawa 2011: 27-29, 44, Siewierska 2011: 57-58). In addition to being non-referential, the subject of the $\mathrm{R}$-impersonal construction is distinctively human and can be expressed with different grammatical means lexically, pronominally, or with the whole construction. In lexical R-impersonals, the subject is typically the word for 'person' or 'people'. In pronominal R-impersonals, the subject may be a pronominalized form of the word 'one', 'person', or 'human', a regular person pronoun, or a special nonspecific pronominal form. For example, the Romance un/uno exemplifies the pronominalized numeral 'one', the Germanic man/men exemplifies the pronominalized noun 'human', the English we, you and they exemplify regular person 
pronouns and the Lithuanian kas nors exemplifies the special nonspecific pronominal form. (Siewierska 2011: 57-58, 2004: 210-213.) ${ }^{1}$

In the R-impersonal constructions under investigation, the unspecified human subject is expressed in verb inflection. It is important to note, however, that in the present study (non)referentiality is not seen as a property of a single word or a morpheme but as a property of a whole construction (also Helasvuo \& Vilkuna 2008: 225). In the end, it is the situational context and the interplay between participants that determine the reference of a certain person construction as specified or unspecified or something in the middle. For this reason, I have also chosen to use the term 'open reference' instead of 'impersonal reference'. As will be demonstrated below, the second- and third-person singular constructions under investigation may also include the speech act participants within the range of referents of the expressed state of affairs (Helasvuo 2008, Suomalainen 2018, Varjo \& Suomalainen 2018, Uusitupa 2017, see also Leinonen 1983: 157), which sets them apart, for example, from the impersonal third-person plural (3PL) that typically has a speaker(and listener-) exclusive interpretation (Siewierska 2011: 62, Posio \& Vilkuna 2013).

Typologically, the 3PL is the most common person form in impersonal constructions. The impersonal usage of 1PL is, instead, clearly restricted to European languages, and the $2 \mathrm{PL}$ forms are often related to functions of politeness, not impersonality. When it comes to the impersonal usages of singular forms, cross-linguistically, 2nd person is much more frequently applied than 1 st and 3 rd persons. (Siewierska 2004: 211-213.) It has been argued that all person forms in Finnish can be applied for open (or impersonal) reference, even though they differ significantly in terms of frequency and use (Helasvuo \& Laitinen 2006). In Karelian, third-person plural and second-person singular are the most common means for impersonal reference (Zaikov 2000: 44, 2013: 170), however, only the latter one is discussed in the following.

In this paper, I will focus on the areal variation and productivity of the abovementioned open second- and third-person singular constructions.

1 Posio and Vilkuna (2013) apply the term human impersonals to emphasise the humanness of the agent in the following R-impersonal constructions in European Portuguese and Finnish: se-impersonal, impersonal 3PL, and impersonal a gente in European Portuguese, and impersonal passive and impersonal 3PL in Finnish. 
By doing so, I will try to shed light on the multifaceted contacts between Karelian and Finnish in the area of Border Karelia and expand the current view of open person constructions applied in Finnic languages. While the Finnish R-impersonals have been studied intensively in recent years (e.g. Laitinen 2006, Helasvuo 2008, Posio \& Vilkuna 2013, Suomalainen 2018, Varjo \& Suomalainen 2018), the same does not hold for smaller Finnic varieties. The overall picture of R-impersonals in the Finnic context is still far from clear, and even the dialectal variation among different R-impersonal constructions in Finnish have by no means been studied exhaustively.

In my doctoral dissertation (Uusitupa 2017), I analysed the Border Karelian open person constructions from functional and interactional perspectives and paid special attention to the on-going speech situation. According to the results, open person constructions in dialectal speech can also be episodic by nature, i.e. instead of referring to everyone, they refer to an individual situated in a given location and time (for more information about the different uses, see Siewierska 2011: 62-65, and Siewierska \& Papastathi 2011). Moreover, it is not uncommon that the speakers use open person constructions when they are clearly talking about themselves and demonstrating their own experience or giving reasons for their own opinion or behaviour (Uusitupa 2017: 122-127). Similarly, it has been pointed out in spoken Estonian that the impersonal verb form does not refer to a generalised or universal referent in its most common uses but rather to a referent that receives more detailed content from the context (Torn-Leesik \& Vihman 2010: 305-306, 313). As noted by Posio and Vilkuna (2013: 223), these types of overlappings between impersonal and personal constructions are presumably due to the fact that impersonal constructions develop from personal ones and vice versa.

\subsection{Border Karelia and Border Karelian dialects}

This section contextualises the discussion by briefly introducing the dialect area in question. The section is mainly based on two earlier published articles (Uusitupa et al. 2017, especially pages 68-73, and Koivisto 2018, especially pages 59-69) that both discuss the history and language contacts of Border Karelia in detail. 
Border Karelia is a historical term that refers to the districts of Impilahti, Korpiselkä, Suistamo, Soanlahti, Salmi and Suojärvi situated on the Finnish-Russian border (Map 1). Before the Second World War, Border Karelia formed the Karelian-speaking part of Finland. The inhabitants of the area were citizens of Finland, but most of them spoke Karelian as their first language. Linguistically and culturally, the eastern parts of Ilomantsi also belonged to Border Karelia. In the treaty of Paris in 1947, however, Border Karelia was incorporated into the Soviet Union, and the Border Karelians were resettled in different parts of Finland. Most of them ended up in the eastern and northern parts of the country, among the Finnish-speaking majority. Currently, Karelian speakers live scattered throughout Finland, and Border Karelia, as a territory with Karelian-speaking majority referred to in this article, no longer exists (for more information about the Karelian-speaking minority in Finland, see Sarhimaa 2017, Palander \& Riionheimo 2018). In Map 1, the black broken line represents the frontier between Finland and the Soviet Union between the years 1917-1945, and the grey line represents the frontier between Finland and the Soviet Union (as of 1991 and onwards, Russia) after the year 1945.

According to the traditional classification (KKS), Karelian is divided in two main dialects: Karelian Proper, comprising North and South Karelian dialects, and Livvi Karelian. ${ }^{2}$ Border Karelian represented the both main dialects: the southern dialects of Karelian Proper were spoken in the districts of Ilomantsi, Korpiselkä, Suistamo and Suojärvi and in the western parts of Impilahti, and Livvi Karelian in the district of Salmi and in the eastern parts of Impilahti. In this article, however, the term 'Border Karelian dialects' refers to both Karelian Proper and Livvi Karelian spoken in the above-defined area.

In addition to Karelian, also Eastern Finnish dialects were spoken in Border Karelia. The change from one Finnic variety to another was smooth and gradual and both areal and idiolectal variation in the area were great. On Map 1, the linguistic borders are illustrated with the black dotted lines: the leftmost line represents the border between Finnish and Karelian, the middle one represents the border between different Karelian dialects and the rightmost represents the border between Karelian and Ludian language.

2 Livvi Karelian is also known as Olonets Karelian. 


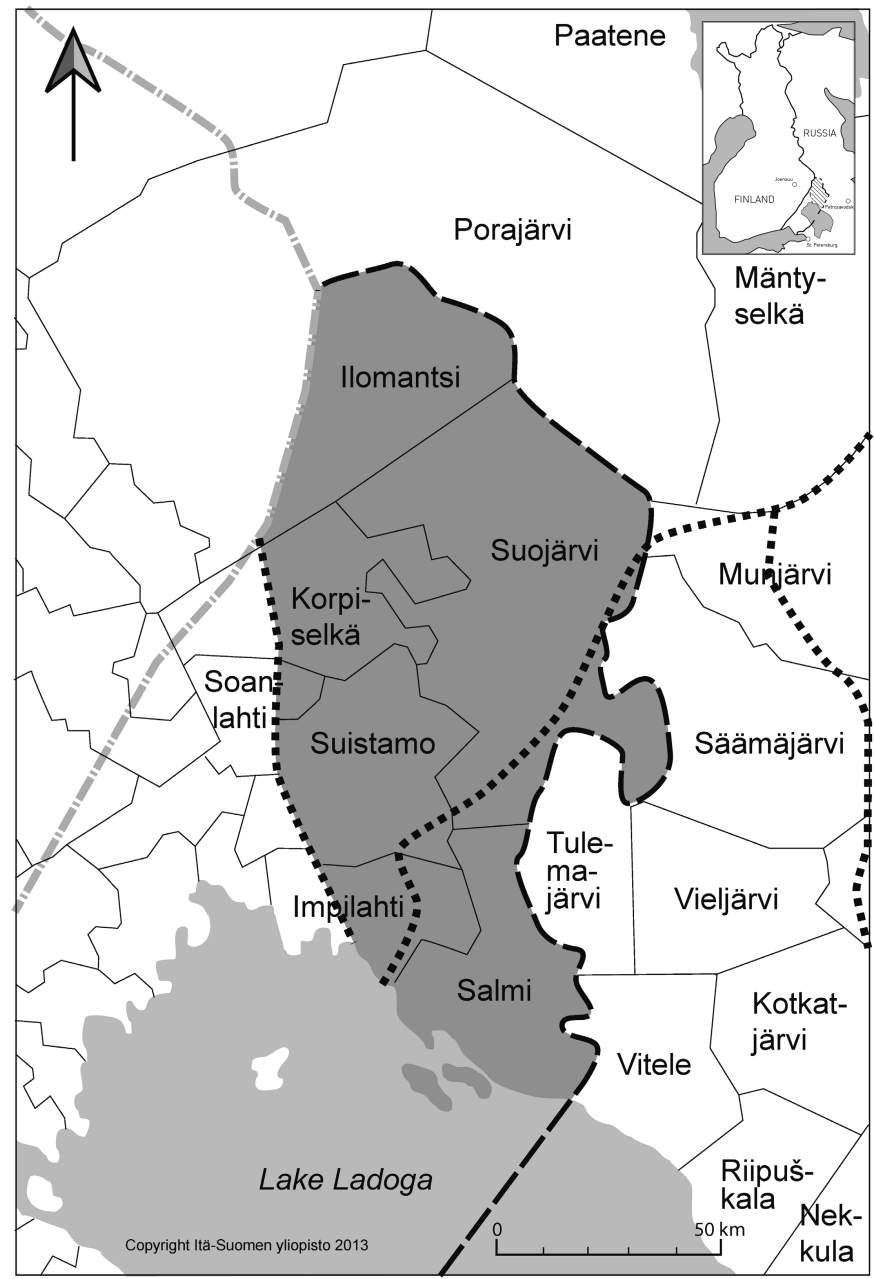

Map 1. Border Karelia by linguistic definition (in grey).

The coexistence of Karelian and Finnish in Border Karelia originated from the events that took place in the early 17 th century. Before that time, Border Karelia was part of Russia, and the population of the area was mainly Karelian-speaking Orthodox. The situation changed in 1617 when Border Karelia became a part of Sweden, and most of the Karelian-speaking population fled eastwards. Some of them settled next to the new border in Olonets Karelia, some walked north to White Sea Karelia, but most of them found new domiciles in the Tver region in Central Russia, a place to which Karelians gravitated to over 
the decades. In the meanwhile, Border Karelia received new inhabitants from the western and southern parts of the Finnish peninsula, who were mainly Lutherans and spoke Finnish Savo dialects. Regardless of the religious, cultural, and linguistic barriers, the two ethnic groups started to live side by side, and the coexistence strongly affected both languages during the following centuries.

New Karelian varieties also started to develop in the Tver region, the place to which Karelians migrated in the 17th century. Although these two Karelians, Border Karelian and Tver Karelian, have a shared history, they have developed into Karelian varieties of their own due to Border Karelian's close proximity to Finnish on the one hand, and Tver Karelian's close proximity to Russian on the other. Because of their common roots, Tver Karelian, however, offers a relevant point of comparison to Border Karelian dialects, and in the present study, the Border Karelian's person system will be compared to the Tver Karelian's system in Section 7.

Karelian is classified as severely endangered language both in Russia and in Finland, and the number of native speakers is decreasing in both countries (Koivisto 2018: 57). This study provides new information about the syntactical structure of Border Karelian dialects spoken in the mid-20th century (see data in Section 4). Earlier research on Karelian dialects has concentrated, for the most part, on vocabulary, phonology, and morphology, and only to a lesser extent on syntactical issues, and even lesser on syntactical issues from a functional point of view (however, Sarhimaa 1999, Oranen 2019). Due to this disparity, the literature referred to in the following sections deals with, for the most part, Finnish, not Karelian.

\subsection{Person marking in Karelian and Eastern Finnish}

In both Karelian and Finnish, the person category is expressed with three separate systems: in personal pronouns, in verbal person marking, and in possessive suffixes. In the following, the main focus is on the verbal one. In Standard Finnish, the predicate verb agrees with the nominative subject both in person and number. In spoken language, however, the system is more complex and variable, as is shown in Table 1 , where two verbs, sanoa $\sim$ sanuo 'say' and voida $\sim$ voija 'may, can', 
are inflected in the present tense indicative mood in Karelian Proper and in Eastern Savo dialects. ${ }^{3}$ The person markers are given in bold.

As shown in Table 1, the biggest differences in person marking between the neighbouring varieties lie in the marking of plural forms. In the Finnish tradition, the unipersonal passive has been included in the person system as the 4th person (originally Tuomikoski 1971, also Helasvuo \& Laitinen 2006). Passive does not make a difference in number, but it has only one form that carries a special person marking, $-h$ in Karelian and $-V h$ in Finnish. In Finnish Savo dialects, the passive form is used also in the 1st person plural, with or without the 1PL pronominal subject (myö sanotaan). ${ }^{4}$ In Karelian, instead, the passive form is generalized in the function of the $3 \mathrm{rd}$ person plural. ${ }^{5}$ In the $3 \mathrm{rd}$ person plural, also the $3 \mathrm{SG}$ verb form is applied with a $3 \mathrm{PL}$ subject in both languages. ${ }^{6}$

Person pronouns are included in Table 1 only in the 1st and 3rd person plural, and even they are put in brackets. If we are talking purely about person marking, subject pronouns are optional both in Karelian and Finnish, and the person can be expressed through the person marking on the predicate alone. However, even though the subject pronoun is not grammatically compulsory, its use might be constrained contextually or pragmatically, and it would be wrong to consider it redundant (for more on the 1SG subject in Finnish dialects, see Väänänen 2016, about the anaphoric 3rd person in Finnish, see Helasvuo \& Laitinen 2006: 179-183). The variation between pronominal and non-pronominal uses and the linguistic and pragmatic factors that explain this variation in spoken language is, however, a matter that is not known in detail yet.

3 The infinitive forms given here and in the following sections are those from Standard Finnish and the dictionary of Karelian (KKS).

4 From Savo, the usage has spread to other dialects and contemporary spoken Finnish (Pertilä 2000: 116-130).

5 Also in Russian and other Eastern Finnic languages, e.g. in Veps, 3rd person plural forms and passive forms are identical (Kehayov 2017: 152). To be precise, however, while in Finnic languages the passive form is generalized in 3rd person plural, in Russian, it is the 3 rd person plural form that is used as passive.

6 If we take a close look at Table 1, we can also see a small difference in person markers of 3rd person singular. In Karelian Proper, $3 \mathrm{SG}$ has three different endings, $-U,-p i$ and $-t$, whereas in Savo, the latter one is unknown. The $t$ ending in 3SG comes in play only in five verb stems with special morphology: nai- 'marry', pui- 'thresh', ui- 'swim', voi'can' and käy- 'walk' (Zaikov 2000: 55-56). 
Table 1. Person marking in Karelian Proper and in Eastern Savo Dialects?

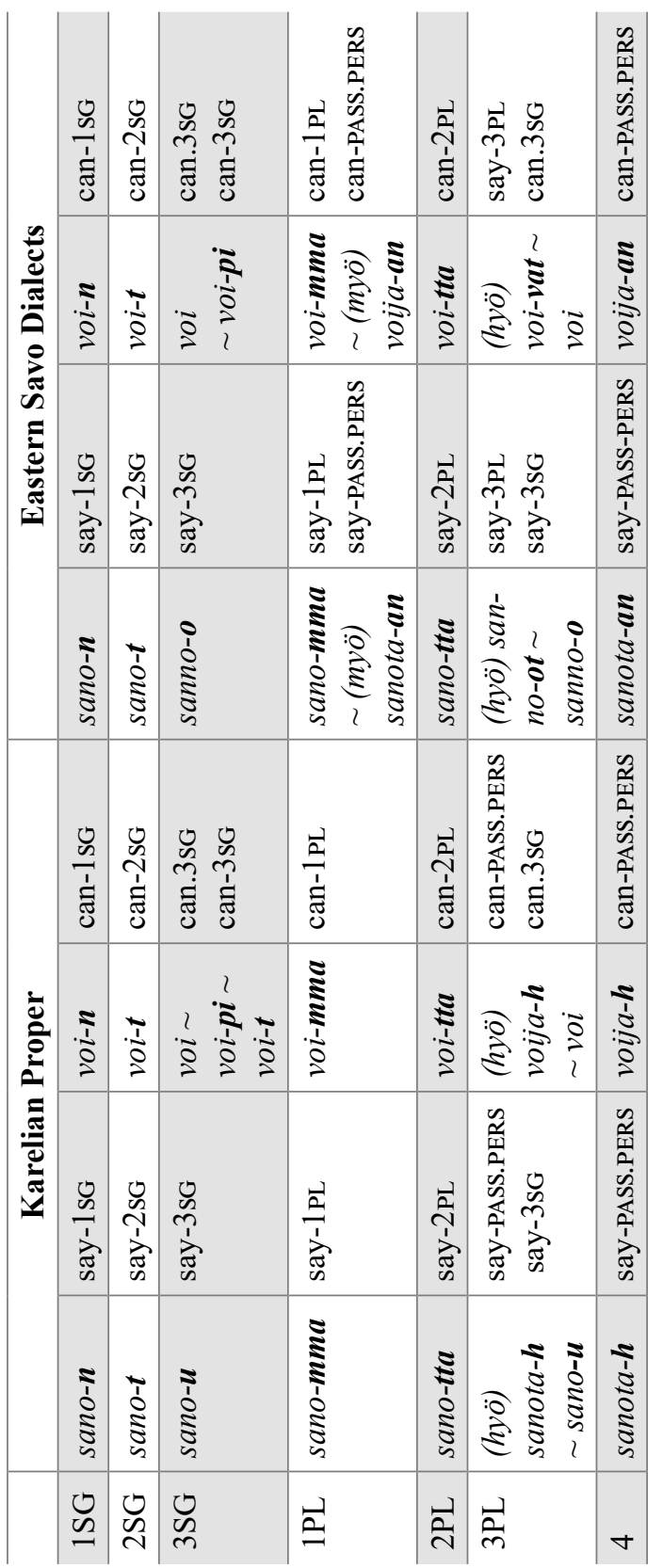

7 Compared to Livvi Karelian, there are some minor differences in plural forms. When in Karelian Proper the person markers of 1PL and 2PL end with a vowel $A$, in Livvi Karelian the final vowel is $O$ (sano-mmo, sano-tto). 
Especially in cases where the same verb form is used for several persons (in Karelian 3PL and 4, and in Finnish 1PL and 4), the subject pronoun (or plural lexical subject in the case of 3PL) plays an important role in anchoring the reference and guiding the interpretation. Because the reference, however, can also be anaphoric by nature, only the wider discourse setting can, in the last resort, reveal the difference.

\section{Constructions under investigation}

\subsection{Zero construction}

The first construction type under consideration is called the zero construction. The name 'zero' refers to the fact that this construction never has an overt subject, but the person is marked in its predicate verb, which appears invariably in the 3rd person singular. Semantically, zero construction implies an unspecified human referent in the described situation (e.g. Laitinen 2006: 212). Example (1) illustrates the use of zero construction in dialectal speech. ${ }^{8}$

(1) Border Karelian

[An interviewee advises on how to make a soup from dried fish:]

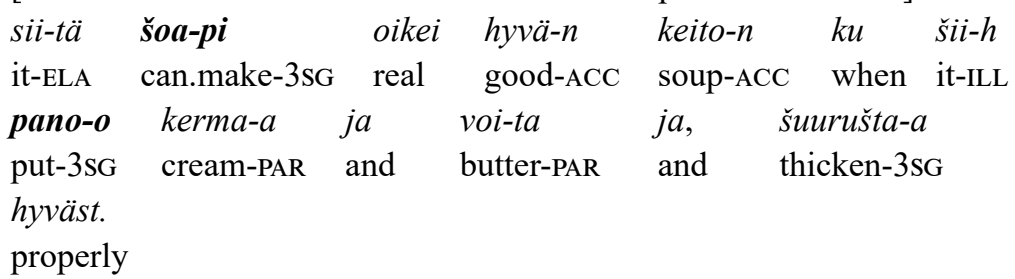

'One can make a real good soup from dried fish when one uses cream and butter and thickens it well' (Ilomantsi 503:1)

8 In English translations, I have used one in 3SG and NEC constructions and you in 2SG and IMP constructions, even though this practice somewhat overplays the semantic difference between the different construction types in Border Karelian dialects. It is, however, essential to note that, in the $3 \mathrm{SG}$ or NEC constructions, there is no overt subject in the Karelian or Finnish counterparts, but the person is coded in the predicate alone. In $2 \mathrm{SG}$ construction, however, the subject pronoun is (at least in theory) possible (see Section 3.3). 
In example (1), the speaker explains how to make fish soup. The short extract contains three instances of the $3 \mathrm{SG}$ verb form, all of which receive an open interpretation in the context. The speaker is not talking (merely) about her own cooking at some specific point of time but in general: 'following these instructions, it is possible (for anyone) to make a good soup'. All three 3SG forms are included in this complex conditional sentence, which has been proven to be one of the most typical clausal contexts for open zero construction (e.g. Laitinen 2006: 212).

In Finnish, the zero construction has been studied intensively during the last decades. It is widely attested that open zero most typically evinces changes of state, emotions, perceptions, and experiences, where the implied human referent is in the role of an experiencer, a beneficiary or a patient. The construction expresses action or activity almost only in complex sentences, most typically in a conditional if-then frame (Laitinen 2006: 212-213, Helasvuo \& Vilkuna 2008: 230-234, Varjo \& Suomalainen 2018). Zero construction belongs to both Standard (e.g. Jokela 2012) and spoken (Varjo \& Suomalainen 2018) varieties of Finnish, and it is also well established in dialects. In contrast to Finnish, in Karelian grammar books the zero construction is not mentioned (however Novak et al. 2019: 272). The following sections will confirm that also based on the empirical data, the usage of zero construction is much more restricted in Karelian than in Finnish.

\subsection{Necessive construction}

The necessive construction resembles the above-introduced zero construction closely in three respects: the predicate is always in the 3 rd person singular, there is no overt subject, and the interpretation is referentially open. There is, however, also a significant syntactic and semantic difference. The predicate of the NEC construction consists of a modal verb (typically expressing necessity) and an infinitive form of a lexical verb. The necessive verbs always appear in the default 3rd person singular form and if they receive a subject, it is in the oblique case. ${ }^{9}$ Hence, the referentially open NEC construction can be assigned as impersonal not only semantically but also morphologically.

9 In other words, the necessive verbs lack person, number and passive inflection. 
(2) Border Karelian

[An interviewer asks, how the grain was reaped and threshed in the old days, and an interviewee explains that the grain was dried and threshed in drying barns:]

No leikattiinko siellä Karjalassa sirpillä?

čirpillä, čirpil leikattii. tiä kai kossaa niitetää ja sitte seipäästetää vaa konehil puijaa

ennem pit-i riihi-löi-s pui-jja.

before have.to-PST.3SG drying.barn-PL-INE thresh-INF

'Was the grain reaped with a sickle?

Yes, it was. Nowadays, instead, the grain is threshed with machines. In the old days, one had to thresh the grain in drying barns [by hand].' (Impilahti 1274:1)

In example (2), the NEC construction is mainly habitual and describes a typical behaviour: 'in the old days, the grain was threshed by hand in special barns built for that purpose'. The construction is not anchored explicitly to the speaker but, based on the contextual information, it is likely that the speaker has experience of this archaic working method. Nonetheless, the identity of the agent is left unspecified and the whole construction remains referentially open.

As described in Section 2.3, normally Finnish and Karelian verbs agree with the nominative subject in person and number. Necessive verbs, however, show no agreement with the primary nominal argument. In Standard Finnish, a necessive verb takes a genitive subject, but dialects have more variation and external local cases (adessive or allative) and the nominative are also possible under certain conditions (Räsänen 1972: 301-303, Laitinen 1992: 112-113). In Karelian, external local cases are applied most often, even though there is variation among different Karelian varieties (Sarhimaa 1999: 105, 118-119, Kehayov \& Torn-Leesik 2009: 389). The most common necessive verb by far in Border Karelian data is pitää piteä 'must, shall, have to', which is widely used also in other Karelian dialects and in Finnish (for more about the usage in Finnish, see Laitinen 1992, and Karttunen 2018: 77-84). In example (2), the verb is in the simple past tense piti and forms a verb chain with an infinitive puijja 'thresh'.

In addition to unipersonal modal verbs expressing necessity, Finnic languages also have modal verbs with person agreement that receive a nominative subject and usually express some type of possibility. 
However, these two modal verb patterns - morphologically impersonal and personal - vary among different Finnic languages and even within one and the same Finnic language (Kehayov \& Torn-Leesik 2009). In Eastern Finnic, i.e. in Karelian, Veps, Ingrian, and Votic, modal verbs expressing possibility also tend to follow the impersonal pattern. In other words, they tend to occur in the default 3 rd person singular and receive primary argument in the oblique case (Kehayov \& Torn-Leesik 2009: 390). According to Kehayov and Torn-Leesik (2009: 390-391), all core modal verbs in Karelian can be used impersonally with adessive-allative case marking on the nominal argument. ${ }^{10}$

Given that the Border Karelian dialects differ from other Karelian varieties owing to strong Finnish influence and that they include ingredients from both languages, the findings presented by Kehayov and Torn-Leesik are highly interesting. As will be demonstrated in the following sections, the third-person singular is applied for open reference in Tver Karelian almost exclusively with modal verbs expressing possibility or necessity, i.e. with verbs that may lack person inflection in Karelian according to Kehayov and Torn-Leesik. In Border Karelian dialects, however, the open usage of the third-person singular clauses is not solely restricted to modal verbs. This raises the question of whether the subjectless but referentially open 3 rd person clauses with modal meaning in the data should be classified as the 3SG type or the NEC type. We will return to this issue in Section 7.

\subsection{Open second-person singular construction}

The third construction type under investigation is open second-person singular. In example (3), the speaker makes a general statement about social norms in the old days: no matter if you were pregnant, the harder you worked, the better. The speaker is not clearly talking about the interviewer, but instead the construction receives an open interpretation.

10 In Karelian Proper, adessive and allative have merged and are marked with an old adessive ending $-l(l A)$. 
(3) Border Karelian

[An interviewee describes life in the old days:]

$\begin{array}{llllll}\text { midä } & \text { enämmär } & \text { ruavo-i-t, } & s e-n & \text { ol- } i & \text { parempi } \\ \text { what } & \text { more } & \text { work-PST-2SG } & \text { it-GEN } & \text { be-PST } & \text { better }\end{array}$

'The harder you worked, the better.' (Impilahti 5129:2)

Example (3) demonstrates that in Border Karelian dialects - as in other Karelian varieties - open 2SG almost never includes a subject pronoun, but the person is only expressed with the person ending in the verb form (ruavoit). In Finnish, the subject pronoun $s \ddot{a}$ is possible in contemporary language (Suomalainen 2018), but in dialects, sinä sie $\sim s \ddot{a}$ is infrequent in referentially open clauses (Forsberg \& Uusitupa 2015) and seems to be used in Border Karelian data only in reported speech (Uusitupa 2017: 227, footnote 143). ${ }^{11}$ Overall, open 2SG is much more rarely used in Finnish dialects than open $3 \mathrm{SG}$, although typologically the situation is the opposite, as described in Section 2.1. In Finnish, open 2SG is applied most productively in Southeastern dialects, as noted already by Sirelius in 1894 (also Forsberg \& Uusitupa 2015). When it comes to Eastern Finnic languages, the situation is, however, drastically different. Both in Karelian and in Veps, 2SG is, along with 3PL, the most common means to construe a generic statement about 'everyone' or 'all people' (Zaikov 2000: 44, 2013: 170, Kettunen 1943: 54-57, Grünthal 2015: 259). As widely attested, both 2SG and 3PL have impersonal usages also in Russian (e.g. Leinonen 1983: 150).

\subsection{Open imperative construction}

The fourth construction type discussed is the open imperative construction. The traditional meaning of an imperative clause has been seen to be directive (for more about directivity, see Honkanen 2012: 8-14). In contrast to directive usage, the speaker does not direct a command or a request to the addressee while using an open imperative clause but, instead, makes a statement about what it is like to be in a particular situation (also Sirelius 1894: 119, Forsberg 2019: 9). Most often, open imperative clauses are used in Border Karelian to express that it

11 Among Finnish dialects, Ingrian Finnish, however, seems to be the exception. Surakka's (2011: 25, 43) data on Ingrian Finnish contain 310 open second-person singular clauses and almost one fourth of them contains a subject pronoun. 
is necessary - or at least advisable - to carry out a certain action. ${ }^{12}$ In example (4), the speaker talks about a shepherd's work. A shepherd was a hired hand and was obligated to look after the cattle, no matter if it was raining or the sun was shining. The interviewee construes this obligation by using two second-person singular imperative clauses, ala männä 'just go' and määl lehmien jäläkee 'just go after the cattle'.

(4) Border Karelian

[About shepherd's work in the old days:]

no uamusilla tuassen kun työnnettii lehmät meččäh, ala

män-nä.

start.IMP.2sG go-INF

olokaapa sae livo, pouta. sinne, määl lehm-i-en jäläkee.

go.IMP.2SG cow-PL-GEN after

'Again, in the morning when the cattle were taken to the forest, you had

to go [to herd them]. No matter if it was raining or shining, you had to go after the cattle.' (Ilomantsi 5315:2)

As in about one-third of the languages of the world, also in Finnish and Karelian the canonical imperative form, the second-person singular, coincides with the verb root and bears no marking of person, mood or tense (Xrakovskij 2001: 23-24, Aikhenvald 2010: 18). ${ }^{13}$ In addition, imperative clauses differ from other second-person singular clauses in that they are genuinely subjectless. As described in Section 3.3, 2SG construction may have a subject pronoun in Border Karelian dialects in reported speech, but in IMP construction, a subject is grammatically impossible. In Example (4), the imperative clauses are translated with the past tense modal verb had to, but grammatically, the imperative forms do not carry tense markers either. Based on the topic and the situational context, it is, however, clear that the statement applies to anyone who used to work as a shepherd in the old days.

12 In addition to necessity, IMP constructions may express possibility or the ease of a certain action (Uusitupa 2017: 150).

13 The imperative does not carry an overt mood marker nowadays in Finnish or Karelian. Historically, the imperative has ended, however, in a consonant, and the old imperative marker $-k$ may still appear in Eastern and Northern Savo dialects of Finnish or cause the phenomenon called border germination under certain conditions (Itkonen 1965: 38, 198-216). Border germination is exemplified in the verb form määl ' go' (Example 4), where the old $k$-morpheme is assimilated to the first consonant of the following word lehmien. Because this phenomenon does not exist in Karelian, Example (4) is again more evidence of the mixed and varied nature of Border Karelian dialects. 
Referentially open IMP construction is known both in Karelian and in Finnish. In Finnish, the usage belongs especially to Eastern dialects (Forsberg \& Uusitupa 2015, see also Uusitupa 2017: 147-148), although some conventionalised patterns are also known in contemporary language (e.g. Lauranto 2014: 53-54). Typologically, conventionalised non-directive usages of imperative clauses are not unheard of (Birjulin \& Xrakovskij 2001: 46-49, Aikhenvald 2010: 234-255). ${ }^{14}$ In the Karelian context, an interesting finding is that the second-person singular imperative clause may serve modal functions and express, among other things, necessity, also in Estonian and Russian (Metslang 2004: 247, Fortuin 2000: 114-134).

\section{Data and methods}

The present study deals with open person constructions in Border Karelian dialects. In total, the data consist of 4,413 referentially open clauses within their contexts, which I have gathered from the Corpus of Border Karelia (Palander et al. 2017). The Corpus of Border Karelia is an unannotated corpus that contains the audio recordings and transcripts of dialect interviews from six Border Karelian parishes - namely Ilomantsi, Impilahti, Korpiselkä, Suistamo, Salmi and Suojärvi. The interviews were done in the 1960s when the Border Karelians had lived for almost two decades in their new domiciles (see Section 2.2). Most of the speakers are quite aged; the oldest ones were born in the 1870s, and the interviewees are mainly asked to tell about the old ways of living. In total, the Corpus contains 118 hours of speech, of which I have used 90 hours (approximately 440,000 words) in the present study (for further details, see Uusitupa 2017: 74-75). ${ }^{15}$

The Tver Karelian comparison corpus, on the other hand, has been compiled from an earlier published language sample collection

14 It is important to note, however, that not all non-directive imperative clauses are referentially open. In Finnish, non-directive but referentially specific imperative clauses can be used, for example, to express a negative stance towards an action performed by an addressee (Forsberg 2019).

15 In addition to the Corpus, I have collected open person constructions from previously published language sample collection (Punttila 1992), which includes two transcribed interviews (5129:2 \& 6854:1) representing Karelian dialects spoken in Impilahti district. 
(Virtaranta \& Virtaranta 1990), which contains approximately 45,000 words transcribed speech from the same time period as the Border Karelian data, from the mid-20th century. Also, the text type is the same: Tver Karelian data represent dialect interviews. The comparisons between Border Karelian and Tver Karelian will be discussed in Section 7.

Because there are no formal criteria on how to distinguish openly used person forms from those used specifically, contextual and paralinguistic information is often crucial to the interpretation of the reference. Consequently, I have not only read the transcriptions but also listened to the Border Karelian interviews. In addition, I have paid special attention to the interplay between the participants. Open person constructions can be used to serve several discourse functions, for example, to indicate how the speaker interprets the topic, the situation, and her or his own position in it. In the following sections, I will, however, focus on the areal and grammatical variation of different construction types, and by doing so, I will propose that what is typical in Finnish, may be untypical in a wider Finnic context.

\section{Areal distribution}

In the preceding, I provided a short summary of each construction type under investigation and its usage in Finnish and Karelian according to earlier literature. Next, I will look into how different construction types vary in Border Karelian data.

In total, the data include 4,413 open person constructions in their contexts. The occurrences can be divided into different construction types in the following manner: 1,310 are type 2SG, 1,206 are type 3SG, 1,661 are type NEC, and 236 are type IMP. Table 2 presents how the occurrences are divided among different Border Karelian parishes, which are listed according to their geographical location: Ilomantsi, listed first, is the westernmost one, and Suojärvi, listed last, is the easternmost one (see Map 1 in Section 2.2). 
Table 2. Open person constructions in Border Karelian data.

\begin{tabular}{l|r|r|r|r|r}
\hline Parish & 2SG & \multicolumn{1}{|c|}{3 SG } & NEC & IMP & Total \\
\hline Ilomantsi & 98 & 272 & 198 & 23 & 591 \\
\hline Impilahti & 192 & 227 & 278 & 34 & 731 \\
\hline Korpiselkä & 322 & 248 & 402 & 37 & 1,009 \\
\hline Suistamo & 239 & 236 & 343 & 84 & 902 \\
\hline Salmi & 167 & 119 & 246 & 31 & 563 \\
\hline Suojärvi & 292 & 104 & 194 & 27 & 617 \\
\hline Total & 1,310 & 1,206 & 1,661 & 236 & 4,413 \\
\hline
\end{tabular}

The data include different amounts of speech from different Border Karelian parishes. The largest data sections are from Impilahti and Suistamo, which contain approx. 95,000 words each, and the smallest data sections are from Salmi and Suojärvi, which contain approx. 55,000 words each. In total, the size of the data set is approx. 440,000 words (for further details, see Uusitupa 2017: 75). Therefore, the absolute token frequencies have been normalised in a way that Figure 1 represents the numbers of each construction type per thousand words.

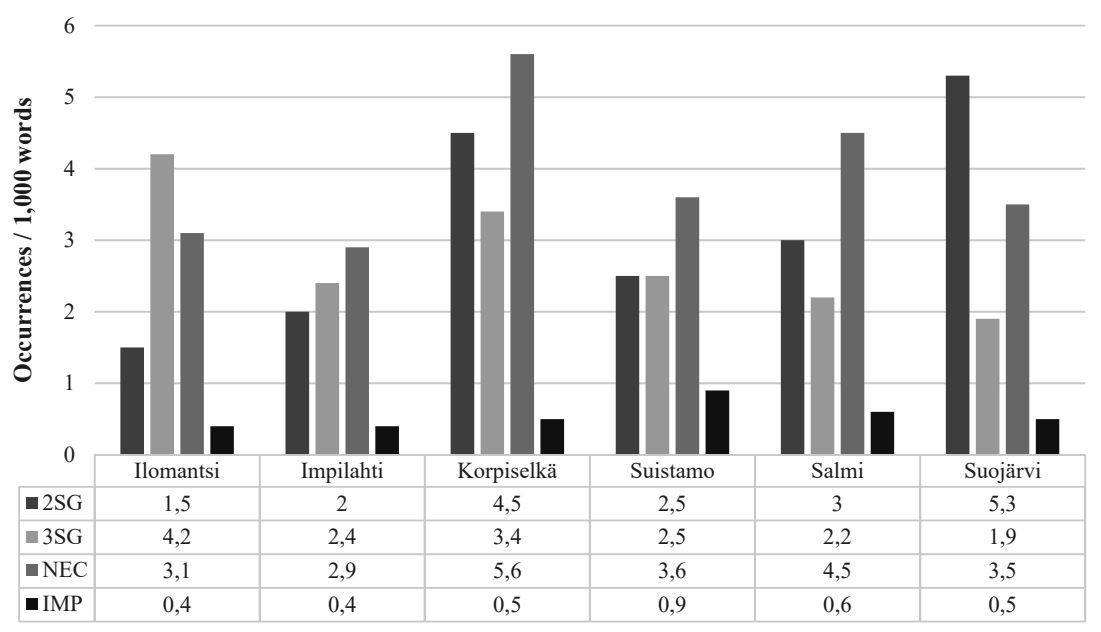

Figure 1. The occurrences of $2 \mathrm{SG}, 3 \mathrm{SG}, \mathrm{NEC}$ and IMP constructions per 1,000 words $^{16}$.

16 Of the total amount of the second-person singular clauses in the data $(\mathrm{n}=1546), 82 \%$ $(\mathrm{f}=1268)$ are in the indicative, $15 \%(\mathrm{f}=236)$ in the imperative, $2 \%(\mathrm{f}=29)$ in the conditional, and $1 \%(\mathrm{f}=13)$ in the potential mood. 
As shown in Figure 1, the clearest differences between data sections lie in the frequency numbers of $2 \mathrm{SG}$ and $3 \mathrm{SG}$ constructions - although in the whole data, the difference in their frequencies is only two tenths: on average, $2 \mathrm{SG}$ is used 3.0 times and 3SG 2.8 times per 1,000 words. 2SG construction is most frequently used in Suojärvi (5.3 times / 1,000 words) and Korpiselkä (4.5 times / 1,000 words) and most rarely in Ilomantsi (1.5 times / 1,000 words). 3SG clauses, on the other hand, are most frequent in Ilomantsi (4.2 times / 1,000 words) and Korpiselkä (3.4 times / 1,000 words) and most rare in Suojärvi (1.9 times / 1,000 words). Thus, the most striking difference lies between Ilomantsi and Suojärvi. In Ilomantsi, 3SG is used almost three times more often than 2SG, whereas in Suojärvi 2SG is used almost three times more often than 3SG. Given that Ilomantsi is the westernmost parish in Border Karelia and that Suojärvi is the easternmost one, Figure 1 indicates that an eastern speaker, who is closer to the heartlands of the Karelian language, uses the second-person more, on average, whereas the western speaker, who is closer to the Finnish Savo dialects, is more likely to employ the zero construction. In other parishes, the difference between $2 \mathrm{SG}$ and $3 \mathrm{SG}$ is not so clear. Open $2 \mathrm{SG}$ construction is, however, more frequently used also in Salmi and Korpiselkä. In Impilahti, 3SG is somewhat more often used (2.4 times / 1,000 words) than 2SG ( $2.0 / 1,000$ words), and in Suistamo, the two types are used exactly equally often (2.5 times / 1,000 words).

When it comes to NEC and IMP constructions, the picture is drastically different because their usages seem to be independent of geography in the same way as the usages of $2 \mathrm{SG}$ and $3 \mathrm{SG}$. As we can see in Figure 1, the NEC construction is relatively common compared to the other construction types across the whole data. Its frequency number varies between 2.9-5.6 times per 1,000 words in different data sections, and on average, the NEC construction is used 3.8 times per 1,000 words. The most frequently used NEC is in Korpiselkä (5.6 times / 1,000 words), where also $2 \mathrm{SG}$ and $3 \mathrm{SG}$ are both used relatively often.

Among the IMP usages, the differences between different parishes are even smaller. On average, IMP construction occurs 0.5 times per 1,000 words. The only exception seems to be Suistamo, where IMP constructions are used almost twice as often as in other parishes ( 0.9 times / 1,000 words). This deviation is, however, plausible to explain by idiolectal, not areal, variation, because one speaker from Suistamo clearly 
favours IMP construction to express different kinds of necessities and possibilities (for further details, see Uusitupa 2017: 146-147). The idiolectal differences are, however, beyond the scope of this article. On a more general level, the findings indicate that also speakers from westerns parts of Border Karelia, who otherwise prefer 3SG instead of 2SG, use referentially open second-person singular imperative clauses.

To summarise: 1) the uses of the 2SG and 3SG constructions are influenced by the speaker's origin, 2) the NEC construction is common across the Border Karelian dialects, and 3) speakers from all localities use IMP, even though there is idiolectal variation in terms of frequency and use. These findings clearly indicate that there is no interdependence between the uses of zero and necessive constructions or between the non-imperative and imperative second-person clauses, but the uses are governed by distinct rules. Consequently, it is reasonable to regard all four as different types to construe an open reference.

\section{Type frequencies}

According to earlier literature, open second-person singular construction can be used more freely with agentive verbs than zero construction in Finnish (Laitinen 2006, Varjo \& Suomalainen 2018). This also seems to hold true in Border Karelian data: the majority of $2 \mathrm{SG}$ constructions evince some kind of concrete action. Figure 2 presents the most frequent verbs used in 2SG construction and Figure 3 the most frequent verbs used in IMP construction.

In Border Karelian data, the open second-person singular typically has a predicate that indicates concrete movement or action, although the ten most frequent verbs also include olla 'be' and the possibility verb saada $\sim$ soaha (+ infinitive) 'get', 'may, can' (Figure 2). In total, the data comprise 1,310 occurrences of $2 \mathrm{SG}$ construction, and these 1,310 occurrences comprise 327 different verbs, of which 179 occur once. If we look at the columns in Figure 2, the two most commonly used verbs mennä männä 'go' and panna 'put' stand out from the rest, but after them, the columns become gradually smaller and smaller. This clearly reveals that the open second-person singular is applied in Border Karelian dialects in multiple ways and its usage is not restricted exclusively to some verb lexemes that are few in number. Turning to 
IMP construction and Figure 3, the most frequently used verbs are ala 'start', mäne 'go', and lähe 'leave'. This trio nicely demonstrate the typical function of IMP in dialectal discourse: the construction often describes transition from one action to another (for further details, see Uusitupa 2017: 150-161). Altogether, 96 different verbs are applied in IMP construction.

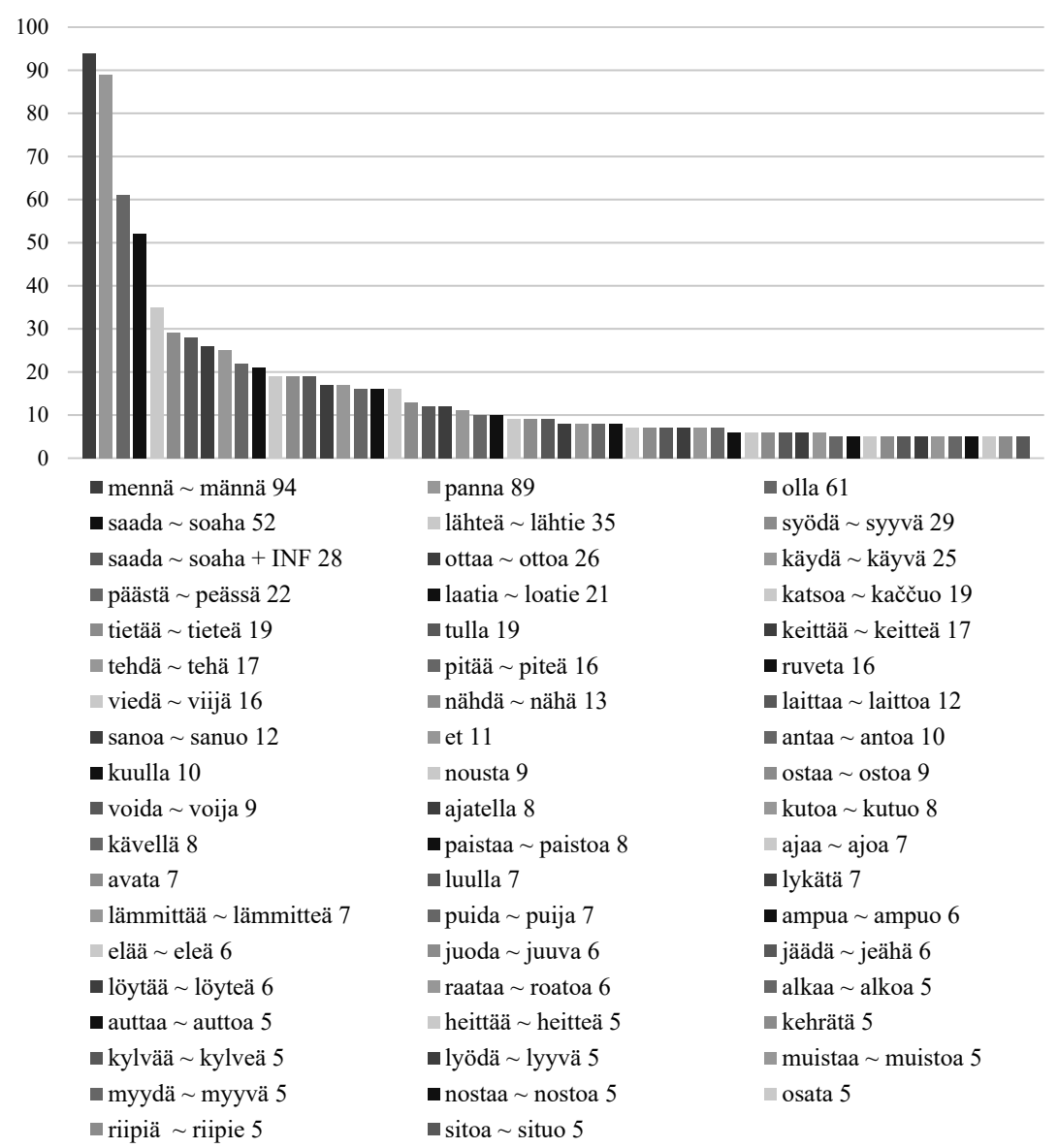

Figure 2. Most frequent verbs in $2 \mathrm{SG}$ construction ( $\mathrm{f} \geq 5$ ). 


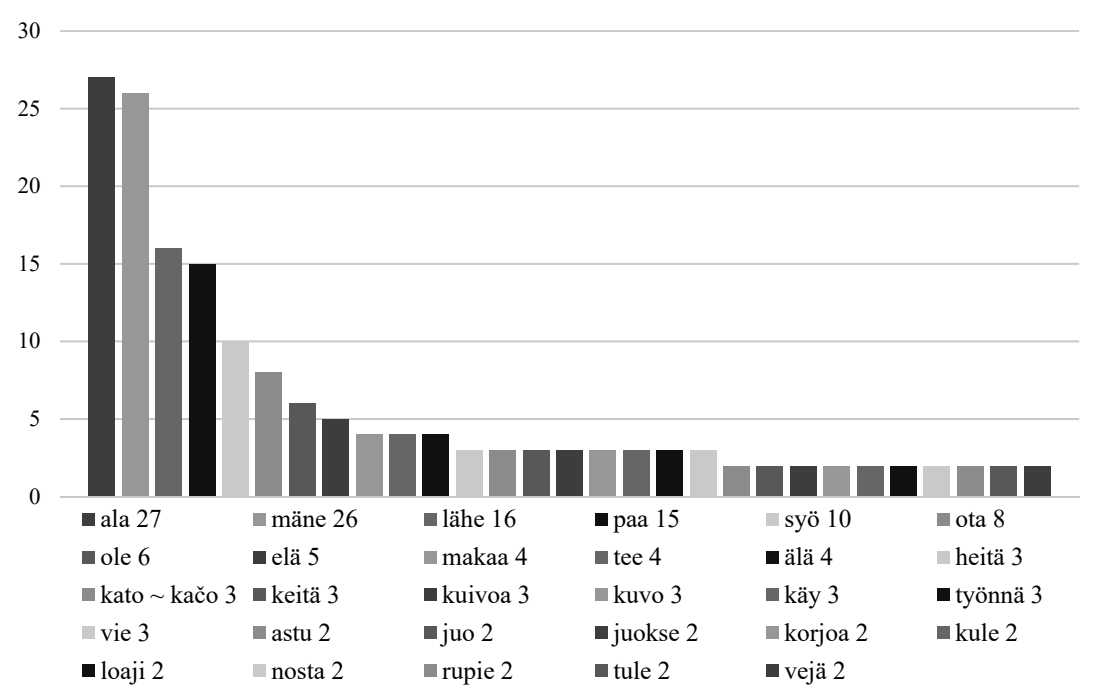

Figure 3. Most frequent verbs in IMP construction ( $\mathrm{f} \geq 2$ ).

When it comes to the zero construction, there is a clear difference compared to the preceding Figures 2 and 3. First, the 3SG construction typically includes a verb chain formed by a modal verb (especially saada soaha 'may, can', 'get', päästä $\sim$ peässä 'get' or voida voija 'can') and an infinitive. Second, the difference in frequency between the two most common verbs and the rest is much sharper than in the preceding as illustrated in Figure 4.

In total, the data contain 1,206 zero constructions, and feature 149 different verbs. Compared to the 2SG type, the size of the verb selection is more than two times smaller. Another clear difference is related to semantics: $3 \mathrm{SG}$ clearly favours predicates that express possibility, cognitive processing, or perception. By far the most frequent predicate is the modal verb saada $\sim$ soaha 'may, can' with an infinitive. The second most used verb is also clear: the verb saada $\sim$ soah $a$ without an infinitive means 'get'. The difference between the two most often used verbs and the rest of the verbs is much more drastic than in Figure 2. In total, the combined number of saada $\sim$ soaha + infinitive and saada $\sim$ soaha occurrences is 643 , which is more than half of the total token frequency of $3 \mathrm{SG}$ constructions. 


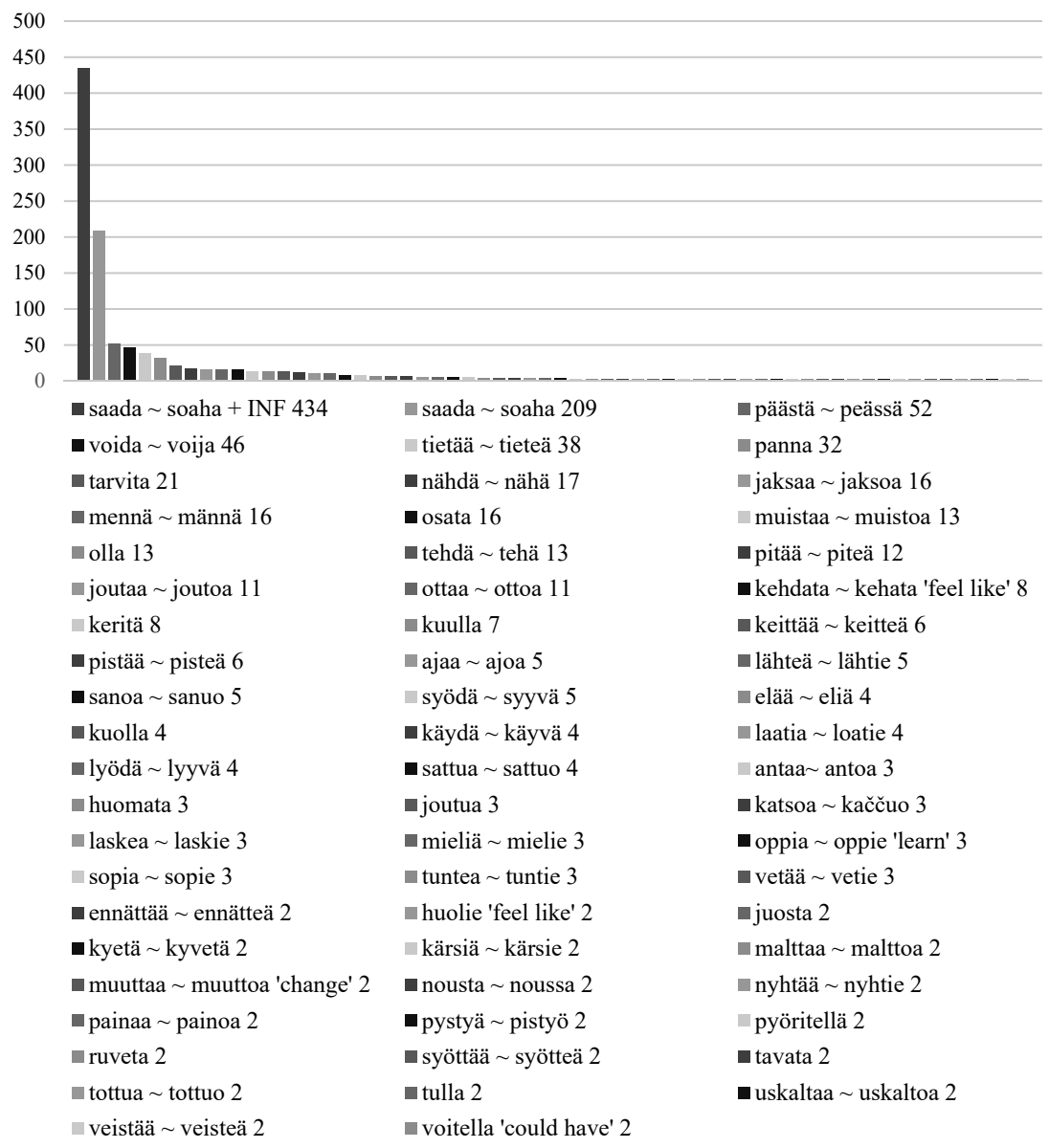

Figure 4. Verbs most frequently used in $3 \mathrm{SG}$ construction ( $\mathrm{f} \geq 2$ ).

Necessive verbs form a closed class, so it is possible to present all unipersonal predicates applied in the NEC construction in Figure 5. As can be seen, by far the most frequently used verb in NEC is pitä̈̈ $\sim$ piteä 'must, have to', which is also widely used in other Karelian and Finnish varieties. Pitää piteä is used 1,475 times, whereas the next most common verb tarvita 'need' occurs 56 times. 


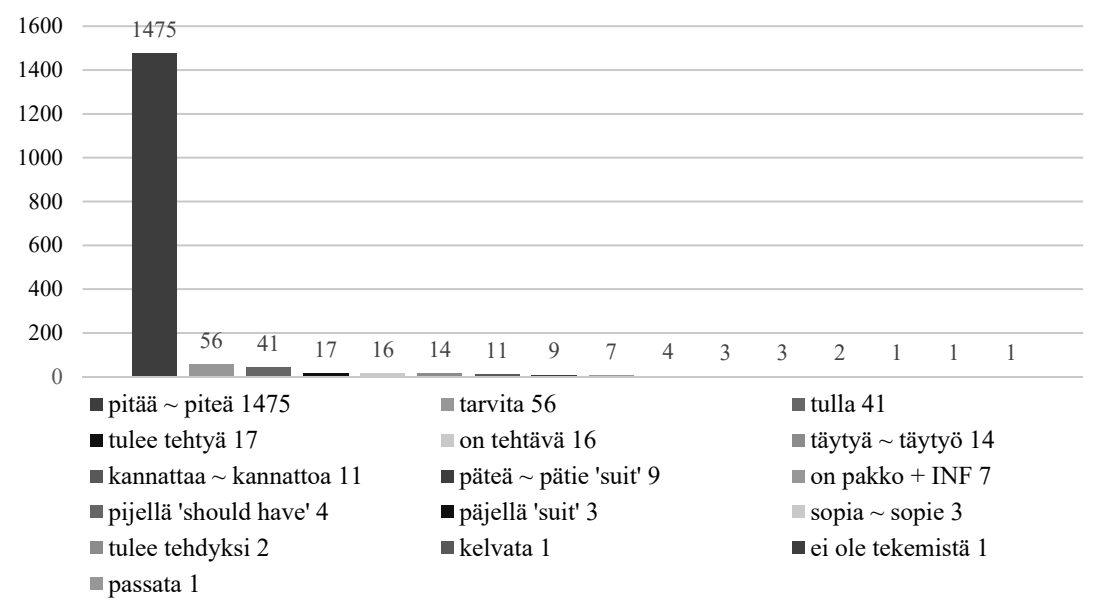

Figure 5. Verbs used in NEC construction.

As shown in previous sections, the type frequencies of $2 \mathrm{SG}$ and $3 \mathrm{SG}$ clearly differ: in $3 \mathrm{SG}$, the two most common verbs are needed to reach the halfway point of the total token frequency of the 3SG type, whereas in $2 \mathrm{SG}$, the 22 most common verbs are needed to reach the halfway point of the total frequency of the type. When it comes to NEC construction, the usage is even more concentrated to just one verb than in 3SG: the NEC construction almost always contains the necessive verb pitää pite $\ddot{a}$. Further, different construction types show a clear preference for a particular verb class. 2SG and IMP constructions favour activity verbs, whereas the vast body of $3 \mathrm{SG}$ constructions includes a verb chain formed by a modal verb (especially saada $\sim$ soaha meaning 'may, can', 'get'). In NEC constructions, by far the most frequently used predicate verb is pitää p pite $\ddot{a}+$ infinitive meaning 'must, have to'. It is worth noting that, in theory, it would be possible to form the referentially open necessive construction also with the 2SG personal pronoun in genitive or a local case, but that is simply not done in the data. ${ }^{17}$ Thus, all the NEC constructions in the Border Karelian data are subjectless and grammatically in the 3rd person singular.

17 Suomalainen (2018: 343-344) has studied open 2SG in contemporary Finnish, and she gives an example of the genitive subject sun 'you.GEN' with the necessive verb pitää 'have to' from conversation data. Also, Surakka (2011: 45-46) presents three NEC clauses from Ingrian Finnish containing the genitive subject siun 'you.GEN'. 
To conclude, the findings presented above renew the strong connection between openly used second-person singular clauses and activity verbs on the one hand and between the third-person singular clauses and modal verbs on the other. Furthermore, they make it possible to ask to what extent "real" zero construction is known in Karelian at all, if all core modal verbs in Karelian can be used impersonally with an adessive-allative subject as stated by Kehayov and Torn-Leesik (2009: 390-391). As will be demonstrated in the next section, this assumption becomes even stronger when one compares Border Karelian data to Tver Karelian, a Karelian variety spoken in Inner-Russia.

\section{Comparisons to Tver Karelian}

This section is based on the Tver Karelian comparison corpus, which was gathered from earlier published language samples (see Section 4). As already described in Section 2.2, Tver Karelian and Border Karelian have common roots in the southern dialects of Karelian Proper spoken in the Swedish-Russian border region in the early 17th century. However, because Border Karelian developed during the following centuries in close contact with Finnish and Tver Karelian in a Russian-speaking environment, Border Karelian and Tver Karelian spoken in the mid20th century are reasonably able to be classified as separate varieties of Karelian language. In the following, I will compare the results of Border Karelian person constructions from Sections 5 and 6 to open person constructions used in Tver Karelian.

The Tver Karelian data contain 1,336 open person constructions, of which 1,099 are second-person singular clauses and 237 third-person singular clauses. From second-person singular clauses, 233 are nonimperative clauses and 4 imperative clauses. The most common verbs used in non-imperative clauses, i.e. in $2 \mathrm{SG}$ construction, are presented in Figure 6, and all the verbs used in the referentially open third-person singular clauses, i.e. in $3 \mathrm{SG}$ and NEC constructions, are presented in Figure $7 .^{18}$

18 The forms given are those from the Tver Karelian dictionary (Punžina 1994). 


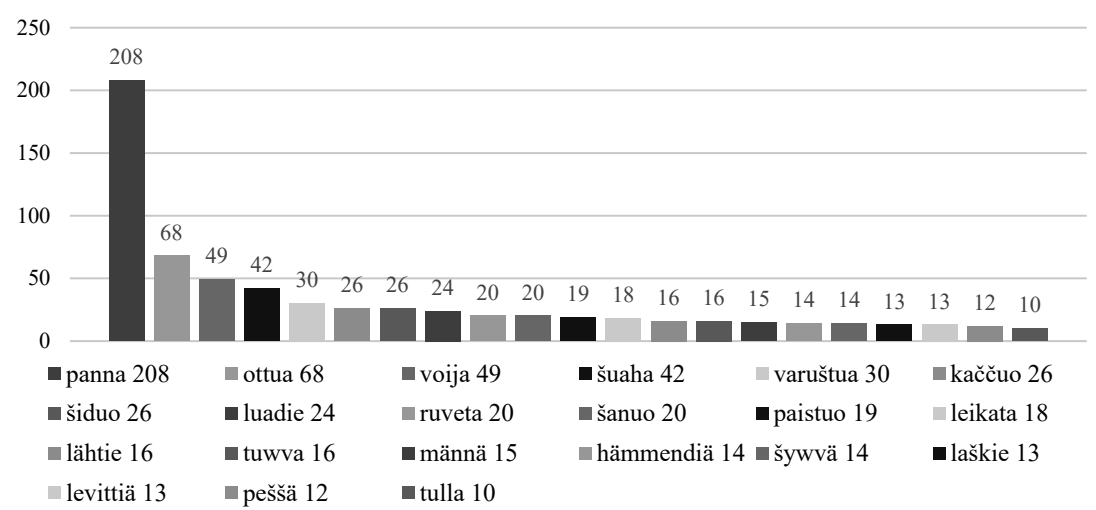

Figure 6. Most frequent verbs in $2 \mathrm{SG}$ construction in Tver Karelian $(\mathrm{f} \geq 10)^{19}$

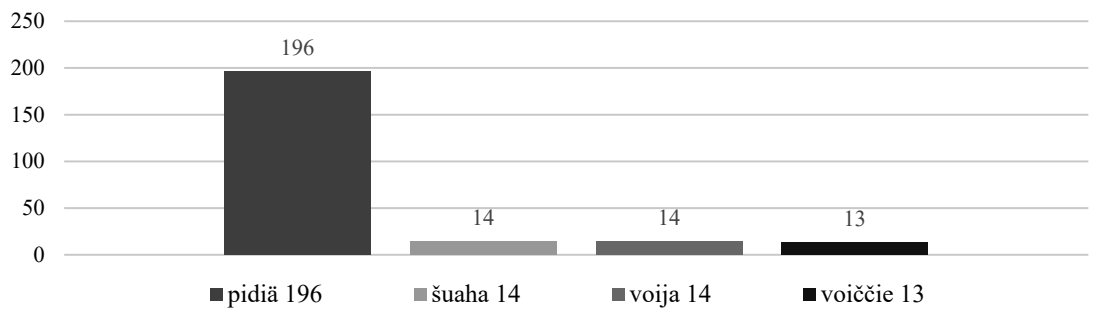

Figure 7. Verbs used in $3 \mathrm{SG}$ and NEC constructions in Tver Karelian.

As Figures 6 and 7 illustrate, the verb collections applied to different persons are considerably different. In total, 188 different verbs are used in 2SG construction. 82 of these occur only once, and 30 of the verbs occur twice. The far most common verb is panna 'put', which encompasses almost one fifth of the total amount of Tver Karelian 2SG constructions and is also the second most common verb in Border Karelian 2SG construction (see Figure 2 in Section 6). Like Border Karelian 2SG constructions, Tver Karelian 2SG constructions hardly ever contain a subject pronoun.

When it comes to Tver Karelian 3rd person clauses, the picture is drastically different. As Figure 7 shows, the majority of occurrences contain a unipersonal necessive verb pidiä 'have to'. In addition, modal

19 The verbs used in the four IMP constructions are hypellä 'jump', kehata 'bother', ottua 'take' and vastata 'knead'. 
verbs šuaha 'can, get', voija 'can' and voiččie 'can' expressing possibility, are used. ${ }^{20}$ The verb selection is highly interesting, because also verbs šuaha and voija have unipersonal usages in the Tver Karelian data, as demonstrated in Examples (5) and (6), where the primary nominal argument is coded with the adessive-allative.

(5) Tver Karelian

$\begin{array}{lllll}\text { Jo } & \text { häne-l'l'äh } & \text { šolahtu- } a & e i & \text { šuanun. } \\ \text { already } & \text { he-ADE } & \text { come.down-INF } & \text { NEG.3SG } & \text { can.PST.CNG }\end{array}$

'He couldn't come down (from the stove)' (Virtaranta \& Virtaranta 1990: 204)

(6) Tver Karelian

$\begin{array}{llll}\text { šiu-l } & e i & \text { voi } & \text { kattšu-o } \\ \text { you-ADE } & \text { NEG.3SG } & \text { can.CNG } & \text { watch-INF }\end{array}$

'You cannot watch (or your eyes will be twisted)' (Virtaranta \& Virtaranta 1990: 52)

The fact that this kind of unipersonal usage with modal verbs is not totally unfamiliar in Border Karelian data either makes this issue even more interesting. According to preliminary findings, at least the possibility verb saada $\sim$ soaha 'can, get' may receive an adessive argument also in Border Karelian dialects (7).

(7) Border Karelian

ei-hä vanho-i-lla sua kävel-lä niin.

NEG.3SG-CLI old-PL-ADE can.CNG walk-INF that way

'Old men cannot walk that way' (Korpiselkä 4376:2a)

Now the noteworthy word is vanhoilla 'old.PL.ADE', which describes people who are not able to walk. Instead of the nominative, the subjectlike-argument is coded with the adessive (-llA), which is often used also with Karelian necessive predicates (see Section 3.2). This means that the modal verb saada $\sim$ soaha behaves like the unipersonal necessive verb pitä̈ $\sim$ piteä and lacks person agreement with the nominal argument. According to Kehayov and Torn-Leesik (2009), the unipersonal (or

20 It is somewhat controversial whether voiččie should be classified as its own verb or as an occurrence of the verb voija, which is just inflected in a different way. In Tver Karelian dictionary, the verbs are not listed separately (Punžina 1994 s.v. voija). 
morphologically impersonal) usage of modal verbs - both expressing necessity and possibility - is known, more or less, in all Eastern Finnic varieties. Most commonly, the verbs pitää, saada and voida (Kehayov and Torn-Leesik 2009: 391) are used impersonally. ${ }^{21}$

To conclude, we can say that the division between openly used second- and third-person clauses in Tver Karelian seems even more clearly defined than in Border Karelian. The 2SG construction in Tver Karelian is productively used with a large number of different verbs that most typically express concrete action (panna 'put' and ottua 'take') or possibility (voija 'can' and šuaha 'can', 'get'). In the meantime, open 3rd person singular clauses are used only with modal predicates expressing either necessity or possibility that clearly differs from the usage of 3SG construction in Border Karelian (see Figure 4 in Section 6). Given that also modal verbs expressing possibility have unipersonal usage in Karelian (Kehayov \& Torn-Leesik 2009), the findings suggest that it would be reasonable to classify all open 3rd person clauses in Tver Karelian data as type NEC, not 3SG.

\section{Conclusions}

This article examined the coexistence of two closely related languages, Finnish and Karelian, in the Border Karelian person system. It demonstrated that even though Finnish and Karelian are each other's closest linguistic relatives, there are significant differences in their ways of person marking, in general, and, most importantly, in their ways of creating an open or impersonal reference. The results confirm that Border Karelian dialects include components from both Eastern Finnish dialects and the Karelian language, and that they constitute a transition zone where the shift from one Finnic variety to another has been smooth and gradual.

As we saw in the analysis presented in Sections 5-7, the different open person constructions have distinct profiles of usage and areal

21 Kehayov and Torn-Leesik (2009: 391-392) argue that the impersonal usage of modal verbs expressing possibility is due to intensive contact with Russian. It has been also proposed that the use of the adessive or dative case in constructions denoting experience, possessing or modality is an areal feature shared by the Russian, Finnic and Baltic languages (e.g. Lindström 2015: 165-166). 
distribution. The more easterly you go in the Border Karelian dialect region, the more frequent the open $2 \mathrm{SG}$ becomes. At the same time, the $3 \mathrm{SG}$ construction becomes more restrictive and more rarely used. However, speakers from all localities use NEC and IMP constructions. These findings suggest that there is no interdependence between the uses of $3 \mathrm{SG}$ and NEC or between the uses of 2SG and IMP. Hence, they should be regarded as four independent construction types that can be used in open reference in Border Karelian dialects - in spite of the fact that neither Karelian nor Eastern Finnish alone use all of them as productively.

A further finding was that all construction types have their own selection of typical predicate verbs. The 2SG and IMP constructions show a clear preference for activity verbs, whereas the vast body of 3SG constructions occur with a modal predicate that expresses possibility (especially saada soaha 'may, can' + infinitive). The NEC construction is used, literally, nine times out of ten with the modal verb chain pitää piteä 'must, have to' + infinitive. Even though this type of distribution has been presented in earlier research, it has not previously been attested with such a large amount of empirical data from spontaneous speech. In addition, in Border Karelian dialects, the selection of verbs used is much wider in the $2 \mathrm{SG}$ than in the $3 \mathrm{SG}$ type. The findings suggest that the second-person singular is used for open reference more productively in Border Karelian dialects than the third-person singular. This conclusion is supported by evidence from the Tver Karelian comparison corpus. In Tver Karelian data, third-person singular clauses are used for open reference only with modal verbs expressing either necessity or possibility. Because possibility verbs may also follow an impersonal modal pattern in Karelian, i.e. lack agreement with the nominal argument, all referentially open third-person clauses in Tver Karelian data could be regarded as occurrences of type NEC, not 3SG. Although it seems a plausible hypothesis that "real" zero construction (the 3SG) is marginal in Karelian and is known in Border Karelian dialects merely because of long-term Finnish influence, this issue still needs to be considered in future research in a larger comparison corpus from different Karelian varieties.

As we saw in the analysis presented in Sections 5-7, the use of different types of modal verbs in referentially open third-person constructions is common both in Karelian and Finnish. Future research should, however, examine the range of the usage of the impersonal 
modal pattern in different spoken Karelian and Finnish varieties. As demonstrated in Section 7, the unipersonal usage of modal predicates expressing possibility is not totally unknown in Border Karelian. As briefly noted in Section 3.2, earlier research has also provided examples from Eastern Finnish dialects where local case marking is used in necessive constructions. An issue that clearly deserves further consideration is whether or not Eastern Finnish modals expressing possibility have similar usage in spoken discourse.

It is also in order to point out that areal distribution does not alone explain the variation of different types in the data, but also contextual, discursive, and idiolectal factors play a role, even though they were left aside in previous discussion. Moreover, the uses of the different open person constructions are probably highly dependent on the range of alternative R-impersonalising strategies available. For example, in Karelian, reflexives and different types of infinitive structures are also used to create an open reference, whereas in Finnish, the impersonal passive construction is very common and is often close to the zero construction in meaning (Uusitupa 2017: 105-106, 137-140). Perhaps even more candidates that serve the same functional domain of R-impersonality will be established in future studies.

In this article, I examined four referentially open person constructions in the border dialects of Finnish and Karelian. The study demonstrated how two systems evincing open reference, the Finnish and the Karelian, meet and come together in Border Karelian dialects and tell the story of multifaceted contacts between two closely related Finnic varieties. From a wider viewpoint, this study underlined the importance of studying minority languages with fewer speakers and lower social status. As demonstrated above, what is characteristic of the largest language of the language group may not be characteristic of the group as a whole.

\section{Acknowledgements}

I would like to thank the anonymous reviewer for their thoughtful comments on earlier version of this paper. All shortcomings are of course my own. This study has been financed by the Academy of Finland (project number 314848). 


\begin{abstract}
Abbreviations
1, 2, 3 - first, second, third person, ACC - accusative, ADE adessive, CLI - clitic, CNG - connegative, ELA - elative, GEN - genitive, ILL - illative, IMP - imperative, INE - inessive, INF -infinitive, NEC - necessive construction, NEG - negation verb, PAR - partitive, PASS - passive, PERS - person marker, PL - plural, PST - past tense, $\mathrm{SG}$ - singular
\end{abstract}

\title{
Data sources
}

Palander, Marjatta, Helka Riionheimo \& Vesa Koivisto. 2017. The Corpus of Border Karelia. University of Eastern Finland \& Institute of the Languages in Finland. http://urn.fi/urn:nbn:fi:lb-2014073033.

Punttila, Matti. 1992. Impilahden karjalaa (Castrenianumin toimitteita 41. Kotimaisten kielten tutkimuskeskuksen julkaisuja 64). Helsinki: Suomalais-Ugrilainen Seura.

Virtaranta, Helmi \& Pertti Virtaranta. 1990. Karjalan kieltä ja kansankulttuuria 1. Tverinkarjalaisia kielennäytteitä (Suomalais-Ugrilaisen Seuran Toimituksia 205). Helsinki: Suomalais-Ugrilainen Seura.

\section{References}

Aikhenvald, Alexandra Y. 2010. Imperatives and commands (Oxford Studies in Typology and Linguistic Theory). Oxford: Oxford University Press.

Birjulin, Leonid A. \& Victor S. Xrakovskij. 2001. Imperative sentences: theoretical problems. In Victor S. Xrakovskij (ed.), Typology of imperative constructions (LINCOM Studies in Theoretical Linguistics 09), 3-50. München: Lincom Europa.

Forsberg, Hannele. 2019. Paheksuntaimperatiivi - affektinen lausekonstruktio. Virittäjä 123(1). 4-43. https://doi.org/10.23982/vir.59164.

Forsberg, Hannele \& Milla Uusitupa. 2015. Yksikön 2. persoonan avoin käyttö suomen murteissa. Section paper presented at the XLII Finnish Conference of Linguistics, 21-23 May 2015. Vaasa: University of Vaasa.

Fortuin, Egbert L. J. 2000. Polysemy or monosemy. Interpretation of the imperative and the dative-infinitive construction in Russian (ILLC dissertation series 2000-7). Amsterdam: Institute for Logic, Language and Computation. https://hdl.handle. net/11245/1.169946.

Grünthal, Riho. 2015. Vepsän kielioppi. Apuneuvoja suomalais-ugrilaisten kielten opintoja varten XVII. Helsinki: Suomalais-Ugrilainen Seura.

Helasvuo, Marja-Liisa. 2008. Minä ja muut. Puhujaviitteisyys ja kontekstuaalinen tulkinta. Virittäjä 112(2). 186-206.

Helasvuo, Marja-Liisa \& Lea Laitinen. 2006. Person in Finnish. Paradigmatic and syntagmatic relations in interaction. In Marja-Liisa Helasvuo \& Lyle Campbell (eds.), 
Grammar from the human perspective. Case, space and person in Finnish (Current Issues in Linguistic Theory 277), 173-207. Amsterdam: John Benjamins.

Helasvuo, Marja-Liisa \& Maria Vilkuna. 2008. Impersonal is personal: Finnish perspective. Transactions of the Philological Society 106(2). 216-245.

Itkonen, Terho. 1965. Proto-Finnic final consonants. Their history in the Finnic languages with particular reference to the Finnish dialects. I: 1 . Introduction. The history of $-\mathrm{k}$ in Finnish (Suomalais-Ugrilaisen Seuran Toimituksia 138(1)). Helsinki: Finno-Ugrian Society.

Jokela, Hanna. 2012. Nollapersoonalause suomessa ja virossa. Tutkimus kirjoitetun kielen aineistosta (Turun yliopiston julkaisuja 334, Sarja C). Turku: University of Turku.

Karttunen, Miia. 2018. No pittää kahttoo. Puhujan tulevan toiminnan ilmausten kielioppia ja pragmatiikkaa (Dissertations in Education, Humanities, and Theology 119). Joensuu: University of Eastern Finland.

Kehayov, Petar. 2017. The Fate of Mood and Modality in Language Death. Evidence from Minor Finnic (Trends in Linguistics. Studies and Monographs 307). Berlin: Mouton De Gruyter. https://doi.org/10.1515/9783110524086.

Kehayov, Petar \& Reeli Torn-Leesik. 2009. Modal verbs in Balto-Finnic. In Ferdinand de Haan \& Bjorn Hansen (eds.), Modals in the languages of Europe: A reference work (Empirical Approaches to Language Typology 44), 363-401. Berlin: Mouton de Gruyter.

Kettunen, Lauri. 1943. Vepsän murteiden lauseopillinen tutkimus (Suomalais-Ugrilaisen Seuran Toimituksia 86). Helsinki: Suomalais-Ugrilainen Seura.

KKS = Virtaranta, Pertti \& Raija Koponen (eds.). 1968-2005. Karjalan kielen sanakirja, osat I-VI. Helsinki: Suomalais-Ugrilainen Seura.

Koivisto, Vesa. 2018. Border Karelian dialects - a diffuse variety of Karelian. In Marjatta Palander, Helka Riionheimo \& Vesa Koivisto (eds.), On the border of language and dialects (Studia Fennica Linguistica 21), 56-84. Helsinki: Finnish Literature Society. https://doi.org/10.21435/sflin.21.

Laitinen, Lea. 1992. Välttämättömyys ja persoona. Suomen murteiden nesessiivisten rakenteiden semantiikkaa ja kielioppia (Suomalaisen Kirjallisuuden Seuran Toimituksia 569). Helsinki: Suomalaisen Kirjallisuuden Seura.

Laitinen, Lea. 2006. Zero person in Finnish. A Grammatical resource for construing human reference. In Marja-Liisa Helasvuo \& Lyle Campbell (eds.), Grammar from the human perspective. Case, space and person in Finnish (Current Issues in Linguistic Theory 277), 209-231. Amsterdam: John Benjamins.

Lauranto, Yrjö. 2014. Imperatiivi, käsky, direktiivi. Arkikeskustelun vaihtokauppakielioppia (Suomi 205). Helsinki: Suomalaisen Kirjallisuuden Seura.

Leinonen, Marja. 1983. Generic zero subjects in Finnish and Russian. Scando-Slavica, Tomus 29. 143-161.

Lindström, Liina. 2015. Subjecthood of the agent argument in Estonian passive constructions. In Marja-Liisa Helasvuo \& Tuomas Huumo (eds.), Subjects in constructions - canonical and non-canonical (Constructional Approaches to Language 16), 141-173. Amsterdam: John Benjamins. 
Malchukov, Andrej \& Akio Ogawa. 2011. Towards a typology of impersonal constructions. A semantic map approach. In Andrej Malchukov \& Anna Siewierska (eds.), Impersonal constructions: A cross-linguistic perspective (Studies in Language Companion Series 124), 19-56. Amsterdam: John Benjamins.

Malchukov, Andrej \& Anna Siewierska. 2011. Introduction. In Andrej Malchukov \& Anna Siewierska (eds.), Impersonal constructions: A cross-linguistic perspective (Studies in Language Companion Series 124), 1-15. Amsterdam: John Benjamins.

Metslang, Helle. 2004. Imperative and related matters in everyday Estonian. Linguistica Uralica 40(4). 243-256.

Novak, Irina, Martti Penttonen, Aleksi Ruuskanen \& Lea Siilin. 2019. Karjala kieliopeissa. Fonetiikan ja morfologian vertaileva tutkimus. Petroskoi: Federation tutkimuskeskus, Venäjän tiedeakatemian Karjalan tiedekeskus, julkaisuosasto.

Oranen, Niklas. 2019. On the use of the adessive case in Tver Karelian. In Annekatrin Kaivapalu, Hanna-Ilona Härmävaara, Johanna Laakso, Maria-Maren Linkgreim \& Raili Pool (eds.), Lähivõrdlusi. Lähivertailuja 29, 205-228. http://dx.doi. org/10.5128/LV29.07.

Palander, Marjatta \& Helka Riionheimo. 2018. Imitating Karelian. How is Karelian recalled and imitated by Finns with Border Karelian roots? In Marjatta Palander \& Helka Riionheimo \& Vesa Koivisto (eds.), On the border of language and dialects (Studia Fennica Linguistica 21), 85-122. Helsinki: Finnish Literature Society. https://doi.org/10.21435/sflin.21.

Pertilä, Laura. 2000. Passiivimuotojen aktiivistuminen suomen kielessä. Sananjalka 42. 115-139. https://doi.org/10.30673/sja.86618.

Posio, Pekka \& Maria Vilkuna. 2013. Referential dimensions of human impersonals in dialectal European Portuguese and Finnish. Linguistics 51(1). 177-229.

Punžina, A. V. 1994. Slovar' karel'skogo jazyka (tverskie govory). Petrozavodsk: Karelija.

Räsänen, Seppo. 1972. Kainuun murteiden kaasussyntaksi (Suomalaisen Kirjallisuuden Seuran Toimituksia 308). Helsinki: Suomalaisen Kirjallisuuden Seura.

Sarhimaa, Anneli. 1999. Syntactic transfer, contact-induced change, and the evolution of bilingual mixed codes. Focus on Karelian-Russian language alternation (Studia Fennica Linguistica 9). Helsinki: Finnish Literature Society.

Sarhimaa, Anneli. 2017. Vaietut ja vaiennetut. Karjalankieliset karjalaiset Suomessa (Tietolipas 256). Helsinki: Suomalaisen Kirjallisuuden Seura.

Siewierska, Anna. 2004. Person (Cambridge Textbooks in Linguistics). Cambridge: Cambridge University Press.

Siewierska, Anna. 2011. Overlap and complementarity in reference impersonals. Manconstructions vs. third-person plural-impersonals in the languages of Europe. In Andrej Malchukov \& Anna Siewierska (eds.), Impersonal constructions. A crosslinguistic perspective (Studies in Language Companion Series 124), 57-89. Amsterdam: John Benjamins.

Siewierska, Anna \& Maria Papastathi. 2011. Towards a typology of third-person plural impersonals. Linguistics 49(3). 575-610. https://doi.org/10.1515/ling.2011.018.

Sirelius, Uuno T. 1894. Lauseopillinen tutkimus Jääsken ja Kirvun kielimurteesta. Helsinki: Suomalaisen Kirjallisuuden Seura. 
Suomalainen, Karita. 2018. Sinä, konteksti ja monitulkintaisuus. Virittäjä 122(3). 320355. https://doi.org/10.23982/vir.63686.

Surakka, Anne. 2011. Yleistävän yksikön 2. persoonan käyttö inkerinsuomessa. Joensuu: University of Eastern Finland MA thesis.

Torn-Leesik, Reeli \& Virve-Anneli Vihman. 2010. The uses of impersonals in spoken Estonian. SKY Journal of Linguistics 23. 301-343.

Tuomikoski, Risto. 1971. Persoona, tekijä ja henkilö. Virittäjä 75(2). 141-152.

Uusitupa, Milla. 2017. Rajakarjalaismurteiden avoimet persoonaviittaukset (Dissertations in Education, Humanities, and Theology 117). Joensuu: University of Eastern Finland.

Uusitupa, Milla, Vesa Koivisto \& Marjatta Palander. 2017. Raja-Karjalan murteet ja raja-alueiden kielimuotojen nimitykset. Virittäjä 121(1). 67-106.

Varjo, Mikael \& Karita Suomalainen. 2018. From zero to 'you' and back: A mixed methods study comparing the use of two open person constructions in Finnish. Nordic Journal of Linguistics 41(3). 333-366. https://doi.org/10.1017/S0332586518000215.

Väänänen, Milja. 2016. Subjektin ilmaiseminen yksikön 1. persoonassa. Tutkimus suomen vanhoista murteista (Turun yliopiston julkaisuja 430, Sarja C). Turku: University of Turku.

Zaikov, Pekka. 2000. Glagol v karel'skom jazyke. Petrozavodsk: Petrozavodsk State University.

Zaikov, Pekka. 2013. Vienankarjalan kielioppi. Lisänä harjotukšie ta lukemisto. Helsinki: Karjalan Sivistysseura.

\section{Kokkuvõte. Milla Uusitupa: Kui soome ja karjala isikusüsteemid kohtu-} vad: avatud isikukonstruktsioonide võrdlus piiriala karjala murretes. Artikkel on täiendus hiljutisele diskussioonile avatud viitesuhtest ja eriti avatud ainsuse teise isiku kasutusest soome keeles ja teistes Euroopa keeltes. Artikkel keskendub neljale avatud viitesuhtega isikukonstruktsioonile - nullkonstruktsioon, netsessiivkonstruktsioon, ainsuse teise isiku ja imperatiivkonstruktsioon - ning nende vastastikusele mõjule ja varieerumisele piiriala karjala murrete suulises diskursuses. Artiklil on kolm eesmärki. Esimene ja peamine eesmärk on osutada, et eelmainitud avatud isikukonstruktsioonid moodustavad neli põhitüüpi. Teiseks, artikkel laiendab käimasolevat diskussiooni avatud viitesuhtest soome keeles, tutvustades ohustatud lähisugulaskeele, karjala keele isikusüsteemi. Kolmandaks tõstatab artikkel küsimuse, kas läänemeresoome keelte kontekstis on nullkonstruktsioon just soome keelele omane viis jätta viitesuhe avatuks ja täpsustamata.

Märksõnad: avatud viitesuhe, impersonaalne viitamine, piiriala karjala murded, karjala keel, soome keel 